\title{
Population genetic structure of the tropical tree species Aegiphila sellowiana (Lamiaceae)
}

\author{
C. Medri' ${ }^{1}$, E.A. Ruas $^{2}$, C.F. Ruas ${ }^{1}$, P.S. Medri ${ }^{3}$, M.E. Medri ${ }^{3}$ and P.M. Ruas ${ }^{1}$ \\ ${ }^{1}$ Departamento de Biologia Geral, Centro de Ciências Biológicas, \\ Universidade Estadual de Londrina, Londrina, PR, Brasil \\ ${ }^{2}$ Departamento de Agronomia, Universidade Estadual de Londrina, \\ Londrina, PR, Brasil \\ ${ }^{3}$ Departamento de Biologia Animal e Vegetal, \\ Universidade Estadual de Londrina, Londrina, PR, Brasil \\ Corresponding author: E.A. Ruas \\ E-mail: edu_wicca@yahoo.com.br
}

Genet. Mol. Res. 10 (4): 3186-3198 (2011)

Received February 11, 2011

Accepted August 3, 2011

Published December 20, 2011

DOI http://dx.doi.org/10.4238/2011.December.20.3

\begin{abstract}
The Tibagi River, located in southern Brazil, is associated with a significant degree of environmental heterogeneity, along its $550 \mathrm{~km}$ extension. There is concern about the integrity of this river's ecosystem, as human interference has been increasing. Aegiphila sellowiana (Lamiaceae) is an important pioneer tree species, commonly found near rivers; the fruit is consumed by avifauna. We studied this species along three ecological gradients, comprising the upper, middle, and lower regions of the Tibagi River basin. The genetic structure of nine subpopulations of $A$. sellowiana distributed along these gradients was investigated using RAPDs. Moderate levels of gene diversity (ranging from 0.091 to 0.132 ) were identified, inferred by a traditional approach and a Bayesian model-based method. The F-statistic, $G_{\mathrm{ST}}$ parameters and molecular variance analysis showed high genetic differentiation among the three regions (39.5 to 50.26\%). Analysis of molecular variance revealed high levels of genetic variation between populations $(50.26 \%)$, while lower values of genetic variation (ranging from 9.56 to $16.35 \%$ ) were seen between subpopulations within
\end{abstract}


the upper, middle, and lower regions of the Tibagi River basin. The validity of these results was confirmed by principal coordinate analysis. Linear regression analysis showed significant correlations $(\mathrm{r}=0.621, \mathrm{P}=$ $0.0001)$ between the genetic and geographical distances. The differences observed in genetic variation between regions are probably due to habitat fragmentation; for conservation purposes, we recommend that at least one subpopulation from each region of the Tibagi River should be maintained.

Key words: Aegiphilla sellowiana; Genetic conservation; RAPD; Genetic diversity; Riparian population; Tropical tree

\section{INTRODUCTION}

In plants, alterations in allelic frequencies that determine their characteristics are correlated with the life cycle (Sales et al., 2001), reproductive system (Dawson et al., 1995), pollen and seed dispersion syndrome (Castellen, 2000), geographic distribution (Hamrick, 1983), and the ability to colonize new environments (Sun and Wong, 2001). At present, human activities must also be cited as responsible for significant events that modify the population genetic structure of plants. In this regard, the human actions in several ecosystems have caused intense habitat fragmentation, resulting in the isolation of individual plants that had previously grouped in a unique metapopulation. The consequence of this process is the establishment of small subpopulations in which distinct evolutionary forces can either operate to modify the genetic structure or, in certain situations, result in extinction. Additionally, high genetic impact of population fragmentation and habitat loss can be expected in small isolated populations with high levels of inbreeding (Lowe et al., 2005).

Environmental heterogeneities can modify the distribution of genetic variability within or among populations of the same species resulting in genetic differentiation over relatively small geographic distances (Knowles, 1984). Fragmentation in Neotropical tree species can provoke an increase in disease and infestation by pests and also the establishment of deleterious alleles over short periods of time (Lowe et al., 2005). In the long-term, it is expected that the loss of genetic variation would greatly reduce the ability of plant populations to positively respond to different selective pressures. Successful management strategies and the preservation of forest tree species are therefore dependent on an accurate assessment of their genetic diversity to address questions regarding the genetic relationships among individuals as well as the levels and structures of their genetic variation. Knowledge of a particular plant population structure also provides a historical perspective of the evolutionary changes that characterize a species and allows researchers to more accurately predict how populations of plants will respond to future events of both natural and artificial origin (Wallace, 2002).

Several techniques and genetic markers have been developed to analyze and estimate genetic diversity among plants. However, no single technique is universally ideal, as all of the available methods for such analyses have both strengths and weaknesses (Mueller and Wolfenbarger, 1999). Random amplification of polymorphic DNA (RAPD) markers have been widely used in the analysis of genetic variation below the species level, despite some noted drawbacks (Hedrick, 1992), particularly in investigations of population structure and differentiation that include the estimation of $F_{\mathrm{ST}}$ analogues and genetic variation within populations (Nybom and Bartish, 2000). Moreover, a recent comparison of different nuclear DNA markers for estimating intraspecific ge- 
netic diversity in plants has also demonstrated that sequence-tagged microsatellite site (STMS) estimates of genetic variability are similar to those determined with dominant RAPD markers (Nybom, 2004). Furthermore, the speed with which RAPD markers can be generated is one of the significant advantages of their use, because they can deliver crucial information within the time constraints that are frequently required to enable urgent conservation decisions (Mueller and Wolfenbarger, 1999). Hence, RAPDs are of great utility in major population genetics applications, notably in the field of genetic conservation, where molecular markers need to be developed at a low cost and in a short time (Hardy, 2003). Furthermore, studies have demonstrated that new statistical approaches, particularly Bayesian methods for estimating population genetic parameters, significantly alleviate the bias related to the dominant nature of RAPDs (Holsinger et al., 2002).

Aegiphila sellowiana is a deciduous pioneer tree species that grows in different types of soil found in secondary, pluvial, and semideciduous forests. This species can reach between 4 and $7 \mathrm{~m}$ in height and display a trunk of $20-30 \mathrm{~cm}$ in diameter, which is characterized by a light and soft wood, commonly used in industry to make furniture, boxes, and wooden shoes. A. sellowiana exhibit simple and opposite leaves that range from 18 to $29 \mathrm{~cm}$ in size and spherical drupe fruits. Flowering occurs during the months of December and January and fruit ripening occurs from February to April. Flowers are honeyed and are pollinated by insects, and trees produce a large number of fruits (Lorenzi, 2002). This species is dioecious and seeds are disseminated by birds (Oliveira and Paula, 2001). When plants are destroyed by fire, cutting or disease, this species shows vegetative propagation by resprouting from roots (Martins et al., 2002).

A. sellowiana was elected for our current study for two main reasons: 1) its ecological importance, as a pioneer plant species, in the recovery of degraded areas and 2) the high level of fragmentation and degradation experienced by subpopulations of $A$. sellowiana that are distributed along the Tibagi River basin, where the original flora has been severely affected by agricultural expansion over the last 50 years.

The specific aims of our study were to measure the amount of genetic variation within and among populations of A. sellowiana to thereby establish the relationships between the molecular data and species biology, natural environment, and habitat degradation at each subpopulation site. The results will be applied in re-vegetation programs of the Tibagi River basin and to guide strategies for species conservation and sustainable utilization.

\section{MATERIAL AND METHODS}

\section{Area of study}

The origin of the Tibagi River in Brazil lies in southern Paraná State at an altitude of $1060 \mathrm{~m}$. The length of this river is approximately $550 \mathrm{~km}$ down to the Paranapanema River at an altitude of $298 \mathrm{~m}$. Situated in the south-northern region of Paraná State, the Tibagi River basin occupies an area of approximately $25,000 \mathrm{~km}^{2}$, corresponding to about $13 \%$ of this state. Because of its geography, the Tibagi River basin is divided into upper, middle, and lower Tibagi, each region characterized by different soil types supporting several environments that are reflected in the diversification of its flora. The upper Tibagi River basin is characterized by dark-red latosoil/litholic soil with a CFb weather type, with light summers, a severe winter and frequent frost. The lower basin is characterized by purple latosoil and a CFa weather type, with hot summers, light winters and only rare frost, while the middle basin has red-yellow 
podzolic soil/dark-red latosoil, with an intermediate $(\mathrm{CFa} / \mathrm{CFb})$ weather type. The flora of the upper Tibagi basin is characterized by a savanna with islands of dense ombrophilous forest, the middle region contains an Araucaria forest, and the lower Tibagi area harbors mostly semideciduous forests (Mendonça and Danni-Oliveira, 2002; Stipp, 2002; Torezan, 2002).

\section{Sampling}

The Tibagi River basin has been severely altered by human activities over the last 50 years and only about $4 \%$ of the original flora are preserved (Torezan, 2002). In our current study, nine subpopulations of $A$. sellowiana were sampled from different regions of the Tibagi River basin comprising: upper $\left(\mathrm{U}_{1}, \mathrm{U}_{2}, \mathrm{U}_{3}\right)$, middle $\left(\mathrm{M}_{1}, \mathrm{M}_{2}, \mathrm{M}_{3}\right)$ and lower $\left(\mathrm{L}_{1}, \mathrm{~L}_{2}, \mathrm{~L}_{3}\right)$ Tibagi (Figure 1).

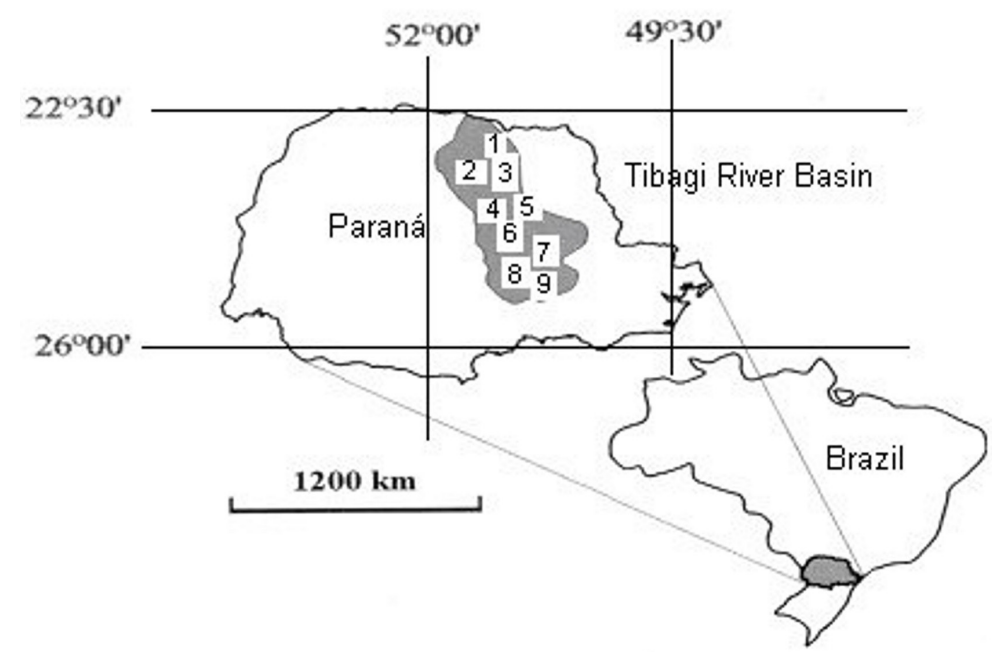

Figure 1. Distribution of nine subpopulations (1-9) of Aegiphila sellowiana along the Tibagi River basin, Paraná State, Brazil.

The criterion for choosing these subpopulations was the occurrence of enough individuals to enable sampling, within a minimal distance of $3 \mathrm{~km}$ between the subpopulations in each of the three regions (Table 1). For genetic analyses, young leaves of 30 individuals, distributed at least $3 \mathrm{~m}$ apart, from each subpopulation were collected.

\begin{tabular}{l} 
Table 1. Geographic localization, altitude, and geographic distances among nine subpopulations of Aegiphila \\
sellowiana distributed along the Tibagi River basin. \\
\hline Subpopulation \\
\hline U1
\end{tabular}




\section{Laboratory procedures}

Genomic DNA was extracted using the CTAB method as previously described (Doyle and Doyle, 1987), except that CTAB was replaced by MATAB (mixed alkyltrimethylammonium bromide; Sigma) in the extraction buffer. The DNA concentration was estimated using a fluorometer (DyNA Quant 200, Höfer-Pharmacia), according to manufacturer instructions, and the samples were adjusted to $10 \mathrm{ng} / \mu \mathrm{L}$ for use in PCR amplifications. A total of 120 primers (Operon Technologies) were tested for amplification and only 18 were selected to amplify the DNA from 270 individual plants. These primers were chosen because of the good amplification pattern, repeatability and the capability of showing polymorphism. PCR was performed in a final volume of $15 \mu \mathrm{L}$ containing the following: 1X PCR buffer $(75 \mathrm{mM}$ Tris-HCl, $50 \mathrm{mM} \mathrm{KCl}$, $2.0 \mathrm{mM} \mathrm{MgCl}_{2}$ and $\left.20 \mathrm{mM}\left(\mathrm{NH}_{4}\right)_{2} \mathrm{SO}_{4}\right) ; 0.2 \mathrm{mM}$ each of dATP, dTTP, dCTP, and dGTP; $0.4 \mu \mathrm{M}$ of each primer; 0.9 U Taq DNA polymerase (Biotools-Spain), and 20 ng template DNA. Amplifications were carried out using a PTC 200X (MJ Research) thermal cycler using the following conditions: $3 \mathrm{~min}$ at $94^{\circ} \mathrm{C}$ followed by 48 cycles of $1 \mathrm{~min}$ at $94^{\circ} \mathrm{C}, 1 \mathrm{~min} 45 \mathrm{~s}$ at $38^{\circ} \mathrm{C}$, and 2 min at $72^{\circ} \mathrm{C}$, with a 7 -min extension step at $72^{\circ} \mathrm{C}$. The samples were then stored at $4^{\circ} \mathrm{C}$ until electrophoresis. Amplified products were resolved on 1.2\% agarose gels in TAE buffer (40X $\mathrm{mM}$ Tris-acetate, $1 \mathrm{mM}$ EDTA, $\mathrm{pH} 8.0$ ) at $110 \mathrm{~V}$ for $3 \mathrm{~h}$ and stained with ethidium bromide.

Only well-resolved fragments were considered for analysis. Homology assessments were made across gels based on an amplified GENE Ruler 100-bp DNA ladder (Fermentas AB, Vilnius, Lithuania). Control samples containing all reaction components except for the template DNA were also run to ensure that no self-amplification or DNA contamination occurred.

\section{Data analysis}

The estimation of allelic frequencies and gene diversity in a plant population using dominant markers can be problematic (Zhivotovsky, 1999). However, Krauss (2000), demonstrated that statistically biased data, obtained from dominant markers such as RAPD, could be eliminated by employing a highly polymorphic marker dataset. It has also been shown that for the accurate estimate of the genetic parameters in a population, about 30 individuals per population should be used besides a large number of dominant loci (Tero et al., 2003).

The within population percentage of polymorphic loci $\left(P_{\mathrm{p}}\right)$ and gene diversity, assuming both with $\left(H_{\mathrm{S}(1)}\right)$ and without $\left(H_{\mathrm{S}(2)}\right)$ Hardy-Weinberg equilibrium (Nei, 1973), were estimated using the POPGEN software (Yeh et al., 2000). The relative magnitude of genetic differentiation $\left(G_{\mathrm{ST}}\right)$ among and within populations (Nei, 1987) assuming the population is either in Hardy-Weinberg equilibrium $\left(F_{\text {IS }}=0\right)$ or completely selfing $\left(F_{\text {IS }}=1\right)$, was calculated using the same software. The analogous Bayesian approach (Holsinger et al., 2002) was also used to directly estimate $G_{\mathrm{ST}}$ and the gene diversity within populations from dominant markers without prior knowledge of the $F_{\text {IS }}$, using the HICKORY software version 1.0 (Holsinger and Lewis, 2003). Several runs were conducted with default sampling parameters (burn-in = 50,000 , sample $=250,000$, thin $=50$ ) to ensure the consistency of the results. Genetic variation within and among populations was further partitioned by analysis of molecular variance (AMOVA) using ARLEQUIN 2.0 (Schneider et al., 2000).

The geographic distances among populations were calculated using the Google Earth program (http://earth.google.com/). To verify possible relationships between the geographic 
and genetic distances, a linear regression was performed using the BIOESTAT4 software (Ayres et al., 2005). Principal coordinate analysis based on genetic distances (Nei, 1978) was carried out using the FAMD program (Schlüter and Harris, 2006). An alternative Bayesianbased clustering method was also applied to infer the number of clusters or subpopulations $(\mathrm{K})$ that was most appropriate for interpreting the data, without prior information on the number of locations at which the individuals were sampled, using the STRUCTURE software version 2.1 with burn-in of 50,000 and MCMC of 500,000 (Pritchard et al., 2000).

\section{RESULTS}

A total of 18 selected RAPD primers generated 252 consistently well-amplified markers. The average percentage of polymorphic loci was lower in the subpopulations of the upper Tibagi (35.32\%; in subpopulation $\mathrm{U}_{3}$ ) than in the subpopulations of the lower Tibagi $\left(52.38 \%\right.$ in subpopulation $\left.\mathrm{L}_{1}\right)$ (Table 2). The average levels of within population gene diversity (Nei, 1973), assuming a Hardy-Weinberg equilibrium $\left(H_{\mathrm{S}(1)}\right)$, were 0.086 for subpopulation $\mathrm{U}_{3}$ and 0.136 for the subpopulation $\mathrm{M}_{2}$. The departure from Hardy-Weinberg equilibrium of within population gene diversity $\left(H_{\mathrm{S}(4)}\right)$ by Bayesian estimates (free model) ranged from 0.091 (subpopulation $\mathrm{U}_{3}$ ) to 0.132 (subpopulation $\mathrm{M}_{2}$ ) (Table 2).

Table 2. Intrapopulation gene diversity in Aegiphila sellowiana from three regions of the Tibagi River basin.

\begin{tabular}{lcccccc}
\hline Region/subpopulation & $\mathrm{N}$ & $P_{\mathrm{P}}(\%)$ & $H_{\mathrm{S}(1)}$ & $H_{\mathrm{S}(2)}$ & $H_{\mathrm{S}(1)}$ & $H_{\mathrm{S}(2)}$ \\
\hline Upper Tibagi & & & & & & \\
$\mathrm{U}_{1}$ & 30 & 51.19 & 0.102 & 0.096 & 0.120 & 0.104 \\
$\mathrm{U}_{2}$ & 30 & 48.41 & 0.108 & 0.104 & 0.126 & 0.111 \\
$\mathrm{U}_{3}^{\text {Average }}$ & 30 & 35.32 & 0.086 & 0.077 & 0.109 & 0.091 \\
Middle Tibagi & & 44.97 & 0.098 & 0.092 & 0.118 & 0.102 \\
$\mathrm{M}_{1}$ & 30 & 41.67 & 0.088 & 0.082 & 0.108 & 0.092 \\
$\mathrm{M}_{2}$ & 30 & 56.35 & 0.136 & 0.125 & 0.146 & 0.132 \\
$\mathrm{M}_{3}$ & 30 & 42.06 & 0.102 & 0.090 & 0.117 & 0.100 \\
Average & & 46.69 & 0.109 & 0.099 & 0.124 & 0.108 \\
Lower Tibagi & 30 & 52.38 & 0.105 & 0.117 & 0.113 & 0.114 \\
$\mathrm{~L}_{1}$ & 30 & 50.00 & 0.113 & 0.127 & 0.119 & 0.122 \\
$\mathrm{~L}_{2}$ & 30 & 40.48 & 0.090 & 0.099 & 0.098 & 0.099 \\
$\mathrm{~L}_{3}$ & & 47.62 & 0.102 & 0.114 & 0.110 & 0.112 \\
Average & &
\end{tabular}

$\mathrm{N}=$ individual number; $P_{\mathrm{p}}=$ polymorphic loci percentage; $H_{\mathrm{S}(1)}=$ Nei's gene diversity with Hardy-Weinberg equilibrium; $H_{\mathrm{S}(2)}=$ Nei's gene diversity without Hardy-Weinberg equilibrium; $H_{\mathrm{S}(1)}=$ Bayesian gene diversity $f=0$ model (with Hardy-Weinberg equilibrium); $H_{\mathrm{S}(2)}=$ Bayesian gene diversity-free model (without Hardy-Weinberg equilibrium).

We estimated the relative magnitude of the genetic differentiation among the natural populations $\left(G_{\mathrm{ST}}=D_{\mathrm{ST}} / H_{\mathrm{T}}\right)$ using traditional (Nei, 1987) and Bayesian approaches, either assuming or not a Hardy-Weinberg equilibrium. In all situations, a high proportion of genetic diversity among populations was revealed with a $G_{\mathrm{ST}}$ ranging from 0.395 to 0.489 (Table 3).

Summaries of AMOVA for all subpopulations of $A$. sellowiana surveyed are shown in Table 4. Of the total genetic variation contained in the nine natural subpopulations examined, $50.25 \%$ could be attributed to differences among populations and $49.75 \%$ to differences among individuals within populations (Table 4D). 
Table 3. Genetic differentiation coefficient $\left(G_{\mathrm{ST}}\right)$, within population gene diversity $\left(H_{\mathrm{S}}\right)$ and total gene diversity $\left(H_{\mathrm{T}}\right)$ among all subpopulations of Aegiphila sellowiana from the Tibagi River basin.

\begin{tabular}{|c|c|}
\hline Genetic structure parameter & Value \\
\hline$G_{\mathrm{ST}(1)}$ - Nei (1987), with Hardy-Weinberg equilibrium & 0.454 \\
\hline$G_{\mathrm{ST}(2)}$ - Nei (1987), without Hardy-Weinberg equilibrium & 0.489 \\
\hline$G_{\mathrm{ST}}-\mathrm{B}_{(3)}-f=0$ Bayesian method & 0.395 \\
\hline$G_{\mathrm{ST}}^{\mathrm{ST}}-\mathrm{B}_{(4)}^{(3)}-f$-free model Bayesian method & 0.452 \\
\hline$G_{\mathrm{ST}}^{\mathrm{ST}}-\mathrm{B}_{(5)}^{(4)}-\theta=0$ Bayesian method & 0 \\
\hline$G_{\mathrm{ST}}^{\mathrm{ST}}-\mathrm{B}_{\mathrm{(S)}}-$ full-model Bayesian method & 0.465 \\
\hline$H_{\mathrm{S}(1)}-$ Nei (1987), with Hardy-Weinberg equilibrium & 0.103 \\
\hline$H_{S(1)}$ - Nei (1987), without Hardy-Weinberg equilibrium & 0.102 \\
\hline$H_{\mathrm{S}(2)}-f=0$ Bayesian method & 0.117 \\
\hline$H_{\mathrm{S}(\mathrm{S})}-f$-free model Bayesian method & 0.107 \\
\hline$H_{\mathrm{S}(5)}-\theta=0$ Bayesian method & 0.204 \\
\hline$H_{\mathrm{S}(\mathrm{S})}$ - full-model Bayesian method & 0.109 \\
\hline$H_{\mathrm{T}(\mathrm{s})}$ - Nei (1987), with Hardy-Weinberg equilibrium & 0.189 \\
\hline$H_{\mathrm{T}(\mathrm{T})}$ - Nei (1987), without Hardy-Weinberg equilibrium & 0.199 \\
\hline$H_{\mathrm{T}(\mathrm{T})}^{\mathrm{(2)}}-f=0$ Bayesian method & 0.193 \\
\hline$H_{T(1)}^{(1)}-f$-free model Bayesian method & 0.196 \\
\hline$H^{1(4)}-\theta=0$ Bayesian method & 0.204 \\
\hline$H_{\mathrm{T}(\mathrm{I})}$ - full-model Bayesian method & 0.204 \\
\hline
\end{tabular}

Table 4. Analysis of molecular variance (AMOVA) for nine subpopulations distributed along three regions of the Tibagi River basin, Paraná State, Brazil.

\begin{tabular}{|c|c|c|c|c|}
\hline $\begin{array}{l}\text { A. Upper Tibagi: subpopulations } \mathrm{U}_{1}, \mathrm{U}_{2}, \mathrm{U}_{3} \\
\text { Variation source }\end{array}$ & d.f. & $\begin{array}{l}\text { Sum of } \\
\text { squares }\end{array}$ & $\begin{array}{l}\text { Variance } \\
\text { components }\end{array}$ & $\begin{array}{l}\text { Percentage } \\
\text { of variation }\end{array}$ \\
\hline $\begin{array}{l}\text { Among subpopulations } \\
\text { Within subpopulations } \\
\text { Total } \\
\text { Fixation index } F_{\mathrm{ST}}=0.16346 \\
\mathrm{P}<0.001\end{array}$ & $\begin{array}{r}2 \\
87 \\
89\end{array}$ & $\begin{array}{r}165.378 \\
1048.400 \\
1213.778\end{array}$ & $\begin{array}{r}2.35461 \\
12.05057 \\
14.40519\end{array}$ & $\begin{array}{l}16.35^{* * *} \\
83.65\end{array}$ \\
\hline \multicolumn{5}{|l|}{$\begin{array}{l}\text { B. Middle Tibagi: subpopulations } \mathrm{M}_{1}, \mathrm{M}_{2}, \mathrm{M}_{3} \\
\text { Variation source }\end{array}$} \\
\hline $\begin{array}{l}\text { Among subpopulations } \\
\text { Within subpopulations } \\
\text { Total } \\
\text { Fixation index } F_{\mathrm{ST}}=0.13805 \\
\mathrm{P}<0.001\end{array}$ & $\begin{array}{r}2 \\
87 \\
89\end{array}$ & $\begin{array}{r}149.156 \\
1117.767 \\
1266.922\end{array}$ & $\begin{array}{r}2.05766 \\
12.84789 \\
14.90556\end{array}$ & $\begin{array}{l}13.80^{* *} \\
86.20\end{array}$ \\
\hline \multicolumn{5}{|l|}{$\begin{array}{l}\text { C. Lower Tibagi: subpopulations } \mathrm{L}_{1}, \mathrm{~L}_{2}, \mathrm{~L}_{3} \\
\text { Variation source }\end{array}$} \\
\hline $\begin{array}{l}\text { Among subpopulations } \\
\text { Within subpopulations } \\
\text { Total } \\
\text { Fixation index } F_{\mathrm{ST}}=0.09565 \\
\mathrm{P}<0.001\end{array}$ & $\begin{array}{r}2 \\
87 \\
89\end{array}$ & $\begin{array}{r}124.467 \\
1297.500 \\
1421.967\end{array}$ & $\begin{array}{r}1.57732 \\
14.91379 \\
16.4911\end{array}$ & $\begin{array}{l}9.56^{* *} \\
90.44\end{array}$ \\
\hline \multicolumn{5}{|l|}{$\begin{array}{l}\text { D. All regions and subpopulations } \\
\text { Variation source }\end{array}$} \\
\hline $\begin{array}{l}\text { Among subpopulations } \\
\text { Within subpopulations } \\
\text { Total } \\
\text { Fixation index } F_{\mathrm{ST}}=0.50249 \\
\mathrm{P}<0.001\end{array}$ & $\begin{array}{c}8 \\
261 \\
269\end{array}$ & $\begin{array}{l}3323.074 \\
3463.667 \\
6786.741\end{array}$ & $\begin{array}{l}13.40378 \\
13.27075 \\
26.67454\end{array}$ & $\begin{array}{l}50.26^{* *} \\
49.75\end{array}$ \\
\hline
\end{tabular}

A. B. C. Totaling three subpopulations by region. D. For all subpopulations. d.f. = degrees of freedom.

The genetic variability between populations is lower when performed only in subpopulations inside the same region (upper, middle, or lower region) (Table 4A-C). When we analyzed the nine subpopulations together, the different statistical approaches consistently in- 
dicated that around $46 \%$ of the genetic variability occurred among the subpopulations, whereas around $54 \%$ of this genetic variation occurred within populations (Tables 3,4). Pairwise $F_{\text {ST }}$ between the subpopulations with the distances in $\mathrm{km}$ are given in Table 5.

Table 5. $F_{\mathrm{ST}}\left(\theta_{\mathrm{B}}\right)$ and genetic distances between pairs of subpopulations of Aegiphila sellowiana.

\begin{tabular}{|c|c|c|}
\hline Interaction & $\theta_{\mathrm{B}}$ & Geographic distance $(\mathrm{km})$ \\
\hline $\mathrm{U}_{1} \times \mathrm{U}_{2}$ & $0.071^{* *}$ & 8.89 \\
\hline $\mathrm{U}_{1}^{1} \times \mathrm{U}_{3}^{2}$ & $0.307 * *$ & 18.48 \\
\hline $\mathrm{U}_{1} \mathrm{xM}_{1}^{3}$ & $0.522 * *$ & 25.67 \\
\hline $\mathrm{U}_{1} \times \mathrm{M}_{2}$ & $0.465^{* * *}$ & 29.92 \\
\hline $\mathrm{U}_{1} \mathrm{x} \mathrm{M}_{3}^{2}$ & $0.522 * *$ & 45.52 \\
\hline $\mathrm{U}_{1} \times \mathrm{L}_{1}^{3}$ & $0.502 * *$ & 103.72 \\
\hline $\mathrm{U}_{1} \times \mathrm{L}_{2}$ & $0.496^{* *}$ & 107.52 \\
\hline $\mathrm{U}_{1}^{1} \times \mathrm{L}_{3}^{2}$ & $0.534 * *$ & 117.72 \\
\hline $\mathrm{U}_{2}^{1} \times \mathrm{U}_{3}^{3}$ & $0.188^{* *}$ & 10.63 \\
\hline $\mathrm{U}_{2}^{2} \times \mathrm{M}_{1}^{3}$ & $0.516^{* * *}$ & 16.86 \\
\hline $\mathrm{U}_{2}^{2} \times \mathrm{M}_{2}$ & $0.454 * *$ & 21.30 \\
\hline $\mathrm{U}_{2}^{2} \times \mathrm{M}_{3}^{2}$ & $0.516^{* *}$ & 36.90 \\
\hline $\mathrm{U}_{2}^{2} \times \mathrm{L}_{1}^{3}$ & $0.506^{* *}$ & 95.09 \\
\hline $\mathrm{U}_{2}^{2} \times \mathrm{L}_{2}$ & $0.497 * *$ & 98.87 \\
\hline $\mathrm{U}_{2}^{2} \times \mathrm{L}_{3}^{2}$ & $0.530 * *$ & 109.18 \\
\hline $\mathrm{U}_{3}^{2} \times \mathrm{M}_{1}^{3}$ & $0.550 * *$ & 9.61 \\
\hline $\mathrm{U}_{3}^{3} \times \mathrm{M}_{2}$ & $0.500 * *$ & 11.96 \\
\hline $\mathrm{U}_{3}^{3} \times \mathrm{M}_{3}^{2}$ & $0.553 * *$ & 27.34 \\
\hline $\mathrm{U}_{3}^{3} \times \mathrm{L}_{1}^{3}$ & $0.546 * *$ & 85.43 \\
\hline $\mathrm{U}_{3}^{3} \times \mathrm{L}_{2}$ & $0.553^{* *}$ & 89.22 \\
\hline $\mathrm{U}_{3}^{3} \times \mathrm{L}_{3}^{2}$ & $0.576^{* *}$ & 99.32 \\
\hline $\mathrm{M}_{1}^{3} \times \mathrm{M}_{2}^{3}$ & $0.149^{* *}$ & 5.86 \\
\hline$M_{1}^{1} \times M_{3}^{2}$ & $0.262 * *$ & 20.53 \\
\hline$M_{1}^{1} \times L_{1}^{3}$ & $0.508 * *$ & 78.51 \\
\hline $\mathrm{M}_{1}^{1} \times \mathrm{L}_{2}^{1}$ & $0.514 * *$ & 82.26 \\
\hline $\mathrm{M}_{1} \times \mathrm{L}_{3}^{2}$ & $0.541 * *$ & 92.72 \\
\hline$M_{2} \times M_{3}^{3}$ & $0.154 * *$ & 5.83 \\
\hline $\mathrm{M}_{2}^{2} \times \mathrm{L}_{1}^{3}$ & $0.463 * *$ & 20.53 \\
\hline $\mathrm{M}_{2}^{2} \times \mathrm{L}_{2}^{1}$ & $0.452 * *$ & 77.60 \\
\hline $\mathrm{M}_{2}^{2} \times \mathrm{L}_{3}^{2}$ & $0.485^{* *}$ & 87.88 \\
\hline $\mathrm{M}_{3}^{2} \times \mathrm{L}_{1}^{3}$ & $0.515^{* *}$ & 58.22 \\
\hline $\mathrm{M}_{3}^{3} \times \mathrm{L}_{2}^{1}$ & $0.506^{* *}$ & 62.01 \\
\hline $\mathrm{M}_{3}^{3} \times \mathrm{L}_{3}^{2}$ & $0.535^{* *}$ & 72.30 \\
\hline $\mathrm{L}_{1}^{3} \times \mathrm{L}_{2}^{3}$ & $0.124 * *$ & 3.91 \\
\hline $\mathrm{L}_{1}^{1} \times \mathrm{L}_{3}^{2}$ & $0.144 * *$ & 14.55 \\
\hline $\mathrm{L}_{2} \times \mathrm{L}_{3}^{3}$ & $0.152 * *$ & 11.33 \\
\hline
\end{tabular}

$* * \mathrm{P}<0.001$.

A significant correlation was identified between the genetic and geographic distances among the nine subpopulation of $A$. sellowiana investigated $(\mathrm{r}=0.621, \mathrm{P}=0.0001)$. This correlation was further confirmed by principal coordinate analysis based on Nei's genetic distance matrix, which explained $51.19 \%$ of the total variation. An obvious geographic pattern was also found among our sample group, which could be divided into three clusters. The first cluster included the subpopulations from the upper Tibagi $\left(\mathrm{U}_{1}, \mathrm{U}_{2}\right.$, and $\left.\mathrm{U}_{3}\right)$ and the second cluster included all plants sampled from the middle Tibagi $\left(\mathrm{M}_{1}, \mathrm{M}_{2}\right.$, and $\left.\mathrm{M}_{3}\right)$. The last cluster consisted of the three subpopulations from the lower Tibagi $\left(\mathrm{L}_{1}, \mathrm{~L}_{2}\right.$, and $\left.\mathrm{L}_{3}\right)$ (Figure 2). Hence, these subpopulations tended to cluster according to their geographic distribution. The estimates of the number of independent populations (K) (Pritchard et al., 2000) gave similar results, suggesting that these populations are not panmictic and the probable number of clusters in this study $(\mathrm{K})$ was $9(\mathrm{P}=0.955)$. 

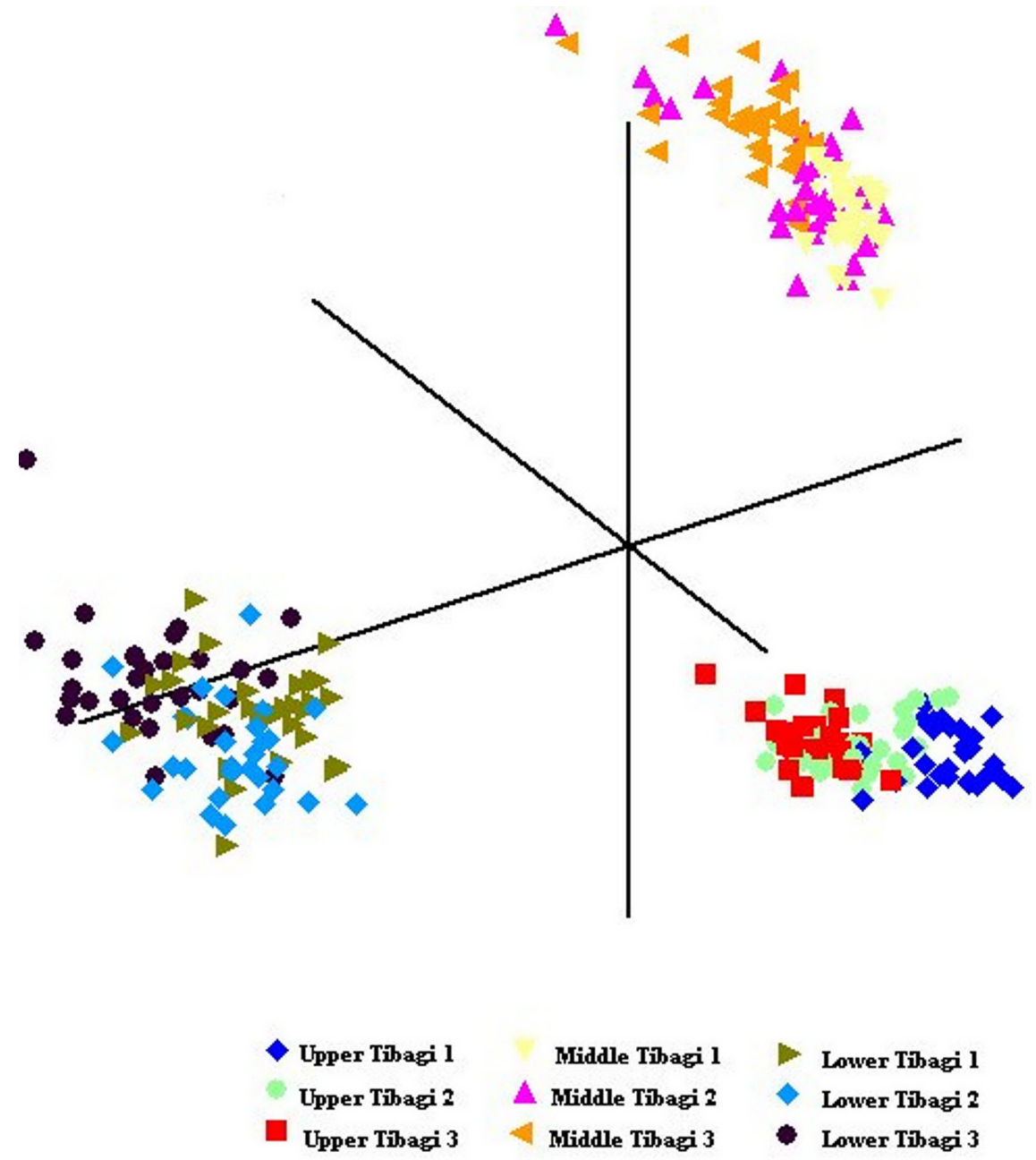

Figure 2. Three-dimensional plot of principle coordinates analysis showing genetic relatedness among nine subpopulations of Aegiphila sellowiana from Tibagi River basin.

\section{DISCUSSION}

\section{Genetic diversity within populations of $A$. sellowiana}

In this study, RAPD markers applied to the analysis of 270 individuals, representing nine natural subpopulations of A. sellowiana, showed moderate levels of total gene diversity and within-population gene diversity (Table 3 ). The values of these parameters are lower than those obtained for other tropical trees with a similar biology. For instance, RAPD markers applied to studies on outcrossing tropical trees have shown a total gene diversity $\left(H_{\mathrm{T}}\right)$ ranging between 0.321 and 0.334 and the within-population gene diversity varying from 0.292 to 
0.309 (Lee et al., 2002; Zimback et al., 2004). Since our sampling size of $A$. sellowiana was 30 individuals per subpopulation, a high accuracy in the estimates of gene diversity is expected.

The low $H_{\mathrm{T}}$ and $H_{\mathrm{S}}$ values (Table 3 ), in relation to other tropical outcrossing tree species previously reported, are therefore likely to be due to a number of factors, including the interactions of human activity, vegetative propagation, and geographic range.

Individually, some subpopulations of $A$. sellowiana displayed lower polymorphism and genetic diversity indices, which differed from other subpopulations present within the same region. For example, considering the upper region the $\mathrm{U}_{3}$ subpopulation showed lower levels of polymorphism and diversity than either the $\mathrm{U}_{1}$ or $\mathrm{U}_{2}$ subpopulation. The $\mathrm{U}_{3}$ subpopulation is located in a limited area where many individual plants are in close proximity and may possibly have originated from a few individuals by vegetative propagation. The same possibility would explain our results for the $\mathrm{L}_{3}$ subpopulation, which also showed a low polymorphism and diversity index when compared with its $\mathrm{L}_{1}$ and $\mathrm{L}_{2}$ counterparts (Table 2).

On the other hand, the $\mathrm{M}_{2}$ subpopulation revealed higher degrees of polymorphism and diversity than did the $\mathrm{M}_{1}$ and $\mathrm{M}_{3}$ subpopulations. In this case, the explanation may be that the individuals in the $\mathrm{M}_{2}$ subpopulation were more widely dispersed throughout a larger area compared with plants from $\mathrm{M}_{1}$ and $\mathrm{M}_{3}$ areas. This type of distribution reduces the number of individuals that originate by vegetative propagation and maximizes the effect of outcrossing, which therefore aids in the maintenance of higher levels of genetic variability.

\section{Population differentiation}

$F_{\mathrm{ST}}$ values estimated by different approaches consistently indicated a high level of genetic differentiation among the subpopulations, accounting for more than $45 \%$ of the total genetic diversity in A. sellowiana. Principal coordinate analysis (Figure 2) also revealed strong genetic differentiation among subpopulations in all of the macro-regions under study. However, a significant separation in the distribution of the three subpopulations inside the same macro-region was not evident, showing that strong environmental forces are responsible for determining the specific genotypes in each region. Thus, we can infer that the differences observed in the $F_{\mathrm{ST}}$ values inside each macro-region were caused by anthropic actions, such as fire and cutting.

A high percentage of genetic variation within populations is commonly found in outcrossing plant species (Hsiao and Lee, 1999). Moreover, species with self-fertilization and/or vegetative propagation usually have a high percentage of genetic variation among populations (Gaudeul et al., 2000). The reproductive biology of A. sellowiana is represented by a mixed system of outcrossing pollination and vegetative propagation. This reproductive system, associated with different habitat conditions along the Tibagi River basin and the strong anthropogenic interference that can cause the fragmentation and isolation of populations, has probably played an important role in shaping the current population structure of these subpopulations.

Restricted migration or geographic separation of habitats has often been used to explain the pattern of variation (Gaudeul et al., 2000), as observed in A. sellowiana. Several studies have demonstrated low to moderate genetic divergence among tropical tree species. Schierenbeck et al. (1997), working with four tropical species from Costa Rica, found a genetic variation of less than $4 \%$ between the plots under study. Studies on tropical plant species showed genetic divergence values of $12.3 \%$ for Plathymenia reticulate from the Brazilian Cerrado (Lacerda et al., 2001) and 12.5 and 17.5\% for two other species from Brazil Trichilia 
pallida (Zimback et al., 2004) and Copaifera langsdorffii (Pinto et al., 2004), respectively. In the current study, a high level of genetic divergence (ranging from 0.395 to 0.495 ) was observed among subpopulations using different statistical approaches. The subpopulations from the upper, middle, and lower Tibagi are adapted to different types of climate, soil, and rain conditions, giving support to the principal coordinate (Figure 2), which accurately clustered these subpopulations according to their region of origin.

\section{Genetic distance $x$ geographic distance and environmental heterogeneity}

A direct correlation between genetic differentiation and geographic distance among individuals and populations has been reported for some outcrossing tropical tree species (Hall et al., 1994). The mechanism underlying this phenomenon involves a reduced gene flow between individuals and populations as the distances separating them become greater.

A linear regression analysis of the geographic $(\mathrm{km})$ and the genetic distances $\left(\theta_{\mathrm{B}}\right)$ between subpopulations of $A$. sellowiana showed a significant correlation between these variables $(\mathrm{r}=0.621, \mathrm{P}=0.0001)$. However, this relationship was not uniform, as it was more related to the differences between regions than differences in subpopulations within the same region, as previously demonstrated by the pairwise $F_{\mathrm{ST}}\left(\theta_{\mathrm{B}}\right)$ (Table 5) and principal coordinate analysis (Figure 2).

In addition, the intense anthropogenic events that have occurred in those regions in the last 50 years have had a huge impact on the heterogeneity of the environment, as these events have involved the removal of most of the original vegetation. Hence, the subpopulations of $A$. sellowiana under study are not in fact the original populations, rather they are the result of the gradual reestablishment of the vegetation of these areas. The individual plants that we sampled probably arose from only a few parents that survived this bottleneck process, intensifying the degree of genetic erosion and, in this way, contributing to an increase in the genetic divergence between the subpopulations across these regions. This also explains the high genetic divergence values between some subpopulations inside these regions, for example $U_{1}$ and $U_{3}$ (0.307), $\mathrm{M}_{1}$ and $\mathrm{M}_{3}(0.262)$ and $\mathrm{L}_{2}$ and $\mathrm{L}_{3}(0.152)$.

\section{Implications for conservation}

The successful management and preservation of forest tree species depend upon an accurate assessment of their genetic diversity, to address issues regarding the genetic relationships among individuals, as well as levels of genetic variation and structure of the plant population themselves. A historic perspective of the evolutionary changes that characterize a species will also allow us to predict how populations will respond to future events of natural and artificial origin (Wallace, 2002).

Our results demonstrate a high genetic differentiation in the subpopulations of $A$. sellowiana distributed in three different climate zones around the Tibagi River basin, suggesting that these subpopulations have different environment-adapted genotypes. The genetic divergences observed in subpopulations within the same area may have originated because of the process of habitat fragmentation, where the majority of the original genetic differences between subpopulations would only be found when they are compared between regions. Aegiphila sellowiana exhibited different levels of genetic diversity within each studied region 
of the Tibagi River basin. Since this species is of great importance in conservation programs aiming to recover degraded forest areas, we may conclude that for conservation purposes a pool of individuals from each of the three regions should be made to enhance the sampling of individuals with alleles adapted to their specific environment.

\section{ACKNOWLEDGMENTS}

We thank Conselho Nacional de Desenvolvimento Científico (CNPq) and Conselho de Desenvolvimento de Pessoal de Nível Superior (CAPES) for providing financial support for the $\mathrm{PhD}$ studies of C. Medri and E.A. Ruas, respectively.

\section{REFERENCES}

Ayres M, Ayres Jr M and Ayres DL (2005). Bioestat: 2.0 - Aplicações Estatísticas nas Áreas das Ciências Biológicas e Médicas. Sociedade Civil Mamirauá, MCT/CNPq, Belém.

Castellen MS (2000). Uso de Marcadores RAPD e Isoenzimáticos na Quantificação da Diversidade Genética em Populações Naturais de Esenbeckia leiocarpa. PhD thesis, ESALQ-USP, Piracicaba.

Dawson IK, Simons AJ, Waugh R and Powell W (1995). Diversity and genetic differentiation among subpopulations of Gliricidia sepium revealed by PCR-based assays. Heredity 74: 10-18.

Doyle JJ and Doyle JL (1987). A rapid DNA isolation procedure for small quantities of fresh leaf tissue. Phytochem. Bull. 19: 11-15.

Gaudeul M, Taberlet P and Till-Bottraud I (2000). Genetic diversity in an endangered alpine plant, Eryngium alpinum L. (Apiaceae), inferred from amplified fragment length polymorphism markers. Mol. Ecol. 9: 1625-1637.

Hall P, Chase MR and Bawa KS (1994). Low genetic variation but high population differentiation in a common tropical forest tree species. Conserv. Biol. 8: 471-482.

Hamrick JL (1983). The Distribution of Genetic Variation Within and Among Natural Plant Populations. In: Genetic and Conservation (Schonewald Cox CM, Chambers SM, Macbride B and Thomas L, eds.). The Benjamin/Cummings Publishing, Menlo Park, 335-348.

Hardy OJ (2003). Estimation of pairwise relatedness between individuals and characterization of isolation-by-distance processes using dominant genetic markers. Mol. Ecol. 12: 1577-1588.

Hedrick P (1992). Shooting the rapids. Nature 355: 679-680.

Holsinger KE and Lewis PO (2003). HICKORY: A Package for Analysis of Population Genetic Data, Version 1.0. Department of Ecology and Evolutionary Biology, University of Connecticut, Storrs.

Holsinger KE, Lewis PO and Dey DK (2002). A Bayesian approach to inferring population structure from dominant markers. Mol. Ecol. 11: 1157-1164.

Hsiao JY and Lee SM (1999). Genetic diversity and microgeographic differentiation of Yushan cane (Yushania niitakayamensis; Poaceae) in Taiwan. Mol. Ecol. 8: 263-270.

Knowles P (1984). Genetic variability among and within closely spaced populations of Lodgepole pine. Can. J. Genet. Cytol.26: 177-184.

Krauss SL (2000). Accurate gene diversity estimates from amplified fragment length polymorphism (AFLP) markers. Mol. Ecol. 9: 1241-1245.

Lacerda DR, Acedo MDP, Lemos Filho JP and Lovato MB (2001). Genetic diversity and structure of natural populations of Plathymenia reticulata (Mimosoidae), a tropical tree from the Brazilian Cerrado. Mol. Ecol. 10: 1143-1152.

Lee SW, Ledig FT and Johnson DR (2002). Genetic variation at allozyme and RAPD markers in Pinus longaeva (Pinaceae) of the White Mountains, California. Am. J. Bot. 89: 566-577.

Lorenzi H (2002). Árvores Brasileiras: Manual de Identificação e Cultivo de Plantas Arbóreas Nativas do Brasil. Plantarum Press Nova Odessa, Nova Odessa.

Lowe AJ, Boshier D, Ward M, Bacles CF, et al. (2005). Genetic resource impacts of habitat loss and degradation; reconciling empirical evidence and predicted theory for neotropical trees. Heredity 95: 255-273.

Martins SV, Riveiro GA and da Silva WM (2002). Regeneração pós-fogo em fragmento de floresta estacional semidecidual no município de Viçosa, Minas Gerais. Cienc. Florestal 12: 11-19.

Mendonça FA and Danni-Oliveira IM (2002). Dinâmica Atmosférica e Tipos Climáticos Predominantes da Bacia do Rio Tibagi. In: A Bacia do Rio Tibagi (Medri ME, Bianchini E, Shibatta AO and Pimenta JA, eds.). Londrina, 63-68. 
Mueller UG and Wolfenbarger LL (1999). AFLP genotyping and fingerprinting. Trends Ecol. Evol. 14: 389-394.

Nei M (1973). Analysis of gene diversity in subdivided populations. Proc. Natl. Acad. Sci. U. S. A. 70: 3321-3323.

Nei M (1978). Estimation of average heterozygosity and genetic distance from a small number of individuals. Genetics 89: 583-590.

Nei M (1987). Molecular Evolutionary Genetics. Columbia University Press, New York.

Nybom H (2004). Comparison of different nuclear DNA markers for estimating intraspecific genetic diversity in plants. Mol. Ecol. 13: 1143-1155.

Nybom H and Bartish IV (2000). Effects of life history traits and sampling strategies on genetic diversity estimates obtained with RAPD markers in plants. Perspect. Plant Ecol. 3: 93-114.

Oliveira PEAM and Paula FR (2001). Fenologia e Biologia Reprodutiva de Plantas de Mata de Galeria. In: Cerrado: Caracterização e Recuperação de Matas de Galeria (Ribeiro JF, da Fonseca CEL and Souza-Silva JC, eds.). EmbrapaCerrados, Planaltina, 301-322.

Pinto SIC, Souza AM and Carvalho D (2004). Genetic variability by isozymes in populations of Copaifera langsdorffii Desf. in two fragments of riparian forest. Sci. Forestry 65: 40-48.

Pritchard JK, Stephens M and Donnelly P (2000). Inference of population structure using multilocus genotype data. Genetics 155: 945-959.

Sales E, Nebauer SG, Mus M and Segura J (2001). Population genetic study in the Balearic endemic plant species Digitalis minor (Scrophulariaceae) using RAPD markers. Am. J. Bot. 88: 1750-1759.

Schierenbeck KA, Skupski M, Lieberman D and Lieberman M (1997). Population structure and genetic diversity in four tropical tree species in Costa Rica. Mol. Ecol. 6: 137-144.

Schlüter PM and Harris SA (2006). Analysis of multilocus fingerprinting data sets containing missing data. Mol. Ecol. Notes 6: 569-572.

Schneider S, Roessll D and Excoffier L (2000). ARLEQUIN: A software for population genetic data analysis, v. 2.0. Genetics and Biometry Laboratory, Department of Anthropology, University of Geneva, Geneva.

Stipp NAF (2002). Principais Tipos de Solos da Bacia do Rio Tibagi. In: A Bacia do Rio Tibagi (Medri ME, Bianchini E, Shibatta AO and Pimenta JA, eds.). EDUEL, Londrina, 39-44.

Sun M and Wong KC (2001). Genetic structure of three orchid species with contrasting breeding systems using RAPD and allozyme markers. Am. J. Bot. 88: 2180-2188.

Tero N, Aspi J, Siikamaki P, Jakalaniemi A, et al. (2003). Genetic structure and gene flow in a metapopulation of an endangered plant species, Silene tatarica. Mol. Ecol. 12: 2073-2085.

Torezan JMD (2002). Nota Sobre a Vegetação da Bacia do Rio Tibagi. In: A Bacia do Rio Tibagi (Medri ME, Bianchini E, Shibatta AO and Pimenta JA, eds.). EDUEL, Londrina, 103-108.

Wallace LE (2002). Examining the effects of fragmentation on genetic variation in Platanthera leucophaea (Orchidaceae): inferences from allozyme and random amplified polymorphic DNA markers. Plant Species Biol. 17: 37-49.

Yeh F, Yang R and Boyle TJ (2000). PopGene 3.12. Microsoft Window-based Freeware for Population Genetic Analysis, Version 1.32, Molecular Biology and Biotechnology Centre, University of Alberta, Edmonton.

Zhivotovsky LA (1999). Estimating population structure in diploids with multilocus dominant DNA markers. Mol. Ecol. 8: 907-913.

Zimback L, Mori ES, Kageyama PY, Veiga RFA, et al. (2004). Estrutura genética de populações de Trichilia pallida Swartz (Meliaceae) por marcadores RAPD. Sci. Forestry 65: 114-119. 